\title{
Microstructure and chemical composition of camel and cow milk powders' surface
}

\author{
Ahmed Zouari $^{\mathrm{a}, \mathrm{b}}$, Pierre Schuck ${ }^{\mathrm{b}}$, Frédéric Gaucheron ${ }^{\mathrm{b}}$, Mehdi Triki ${ }^{\mathrm{a}}$, Guillaume Delaplace ${ }^{\mathrm{c}}$, \\ Claire Gauzelin-Gaiani ${ }^{\mathrm{d}}$, Christelle Lopez ${ }^{\mathrm{b}}$, Hamadi Attia ${ }^{\mathrm{a}}$, Mohamed Ali Ayadi ${ }^{\mathrm{a}, *}$ \\ ${ }^{a}$ Valuation, Security and Food Analysis Laboratory, National Engineering School of Sfax, Sfax University, Tunisia \\ ${ }^{\mathrm{b}}$ Science and Technology of Milk and Egg, INRA, Agrocampus-ouest, Rennes, France \\ ${ }^{\mathrm{c}}$ UMET, Processus Aux Interfaces et Hygiène des Matériaux, Villeneuve d'Acsq, France \\ ${ }^{\mathrm{d}}$ Laboratoire d'Ingénierie des Biomolécules (LIBio), Université de Lorraine, Nancy, France
}

\section{A R T I C L E I N F O}

\section{Keywords:}

X-ray photoelectron spectroscopy

Surface composition

Camel milk powder

CLSM

SEM

\begin{abstract}
A B S T R A C T
This study aimed at investigating the chemical composition and microstructure of spray dried camel and cow

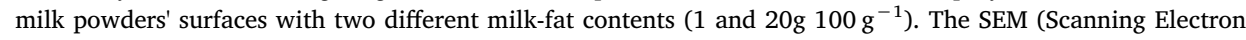
Microscopy) micrographs showed that spherical particles with a 'brain'-type surface for both milk powders were produced. The surface roughness (Ra) of whole (WDMP) and skimmed (SDMP) camel milk powders $(\mathrm{Ra}=7.6 \pm 0.4 \mathrm{~nm}$ and $5.6 \pm 0.7 \mathrm{~nm}$, respectively) were significantly lower as compared with the partially skimmed (PSCMP) and skimmed (SCMP) cow milk powders. The XPS (X-ray Photoelectron Spectroscopy) analysis highlighted that the surface of skimmed camel milk powders contained twice the lactose amount $(17.7 \pm 0.8 \%)$ as compared to cow milk powders $(8.7 \pm 0.4 \%)$. Furthermore, both milk powders showed the overexposure of proteins and fats at their surfaces regardless of the fat content. The CLSM (Confocal Laser Scattering Microscopy) micrographs highlighted that most of the camel milk fat globules were encapsulated by the proteins near the powder surface. Camel milk fat behavior during particle formation was attributed to their lower size distribution and their higher crystallization temperature.
\end{abstract}

\section{Introduction}

Most of the milk powders are commonly produced using spray drying technique, which is a dehydration method involving a quick water removal from small milk droplets exposed to a flow of dry and hot air. In this process, it was acknowledged that the milk's nutritional and functional qualities are preserved, since moderated drying conditions are often applied (Roos, 2002; Schuck, Dolivet, Méjean, \& Jeantet, 2008).

During drying process, fats, proteins, lactose and minerals (the four main compounds of milk) are transported to the powder's surface showing different concentrations and locations according to their nature (Gaiani et al., 2009; Murrieta-pazos, Gaiani, Galet, \& Scher, 2012). In fact, two mechanisms are known to describe the development of milk powder's surface, including the air/liquid interface interaction (through active substances) (Fäldt \& Bergenståhl, 1994) and the solid/ solutes segregation (Kim, Dong Chen, \& Pearce, 2003). In both systems, proteins and fats (even at low concentration) start to accumulate preferentially at the surface (in the first $5 \mathrm{~nm}$ ) of the milk powder particles
(Gaiani et al., 2009; Kim, Chen, \& Pearce, 2002; Kim et al., 2003; Murrieta-Pazos et al., 2011; Shrestha, Howes, Adhikari, Wood, \& Bhandari, 2007).

Previous studies of camel milk highlighted some deep natural differences concerning the physicochemical characteristics of proteins (e.g. lack of $\beta$-lactoglobulin and higher casein micelles size) and fats (e.g. lower fat globule size) when compared to cow milk (Felfoul, Jardin, Gaucheron, Attia, \& Ayadi, 2017; Mehaia, 1995; Merin et al., 2001; Zouari et al., 2018). Such differences could change the transport of fat, protein, lactose and minerals towards the powder surface during drying. The surface composition of cow milk powders has been extensively studied using the X-ray photoelectron spectroscopy (XPS) (Gaiani et al., 2011; Kim et al., 2002). The XPS is well-established technique that measures the distribution of relative atomic elemental composition at a studied surface (thickness of 5-10 nm) (Nawaz, Gaiani, Fukai, \& Bhandari, 2016). The elementary composition of several biological materials, such as milk powders, is mainly divided into three elements, which are carbon, oxygen, and nitrogen. In case of milk powders, these elements are used to quantify the surface composition in

\footnotetext{
* Corresponding author. LAVASA, ENIS, BP, 3038, Sfax, Tunisia. Tel./fax: 0021674675761.

E-mail addresses: ahmedzouarri@gmail.com (A. Zouari), ayadimedali@gmail.com (M.A. Ayadi).
} 
term of proteins, fats and lactose (Fäldt \& Bergenståhl, 1994; Nikolova et al., 2015). Indeed, the XPS survey is composed of several peaks including the $\mathrm{O} 1 \mathrm{~s}, \mathrm{~N} 1 \mathrm{~s}$, and $\mathrm{C} 1 \mathrm{~s}$. These peaks can be further deconvoluted into specific sub-peaks at different binding energies. The resulting subpeaks describe some well-identified chemical functions (e.g. C-C $(\mathrm{H})$, $\mathrm{C}-\mathrm{O}, \mathrm{C}-\mathrm{O}, \mathrm{O}-\mathrm{C}=\mathrm{O}$ etc.), which are specific for proteins, fats, and lactose.

Actually, few researchers have investigated the production of the spray-dried camel milk powders. These works described their sensorial and physical characteristics as well as their use as an ingredient in ice cream formulations (Abu-Lehia, 1998; Abu-Lehia, Al-Mohizea, \& ElBehry, 1989; Sulieman, Elamin, Elkhalifa, \& Laleye, 2014). However, none of these studies have evaluated the characteristics of camel milk powders' surface. Therefore, the overall aim of this study was to identify the aspect and the composition of whole and skimmed camel milk powders' surface in relation with the fat globules behavior during drying. In order to create a comparative study, cow milk powders were produced under the same dehydration conditions and were evaluated following the same characterization techniques.

\section{Materials and methods}

\subsection{Milk samples}

Fresh whole camel (Camelus Dromedarius) and cow (Bos Taurus) milks were obtained from nine lactating females (three to six months) located in Tunisian dairy farms (Gabes and Sfax governorates, respectively). Both milks were stabilized against the microbiological development by adding $0.02 \%(\mathrm{w} / \mathrm{w})$ of sodium azide. Some of whole cow ( $40 \mathrm{~g} \mathrm{~L}^{-1}$ of fat) and camel ( $27 \mathrm{~g} \mathrm{~L}^{-1}$ of fat) milks were totally skimmed ( $1 \mathrm{~g} \mathrm{~L}^{-1}$ of fat) after one or three successive skimming operations (2000 $\mathrm{g}, 5{ }^{\circ} \mathrm{C}$ for $10 \mathrm{~min}$ ). In addition, samples from whole cow milk were also partially skimmed ( $100 \mathrm{~g}, 5^{\circ} \mathrm{C}$ for $5 \mathrm{~min}$ ) to reach the same fat content of whole camel milk. The camel and cow milks' fat globules size distribution was assessed using a Mastersizer 2000 (Malvern Instruments Ltd., Malvern, UK, equipped with a $5 \mathrm{~mW} \mathrm{He}-\mathrm{Ne}$ laser and operating at a wavelength of $633 \mathrm{~nm}$ with 300 Flens).

\subsection{Powders production and chemical analysis}

Camel and cow milk samples were immediately spray dried using a Büchi mini spray dryer B-290 (Büchi Labortechnik AG, Flawil, Switzerland). The absolute humidity of air was equal to $5 \mathrm{~g}$ of water per $\mathrm{kg}$ of dry air. The inlet and outlet drying temperatures $\left(175 \pm 1{ }^{\circ} \mathrm{C}\right.$ and $75 \pm 1{ }^{\circ} \mathrm{C}$, respectively) were controlled through managing the feed rate $\left(0.8 \pm 0.1 \mathrm{~kg} \mathrm{~h}^{-1}\right)$ (Walstra, Walstra, Wouters, \& Geurts, 2005). The average residence time of milk droplets in the drying chamber was close to $1 \mathrm{~s}$. The produced camel and cow milk powders (average yield $65 \pm 5 \%$ ) were immediately stored at $4{ }^{\circ} \mathrm{C}$ in sterilized glass vials.

The biochemical composition (protein, fat, lactose, and ash) of the produced powders (WDMP: whole camel milk powder, PSCMP: partially skimmed cow milk powder, SDMP: skimmed camel milk powder, SCMP: skimmed cow milk powder) was evaluated as described by Schuck, Jeantet, and Dolivet (2012).

The surface free fat content (SFFC) was estimated by mixing $10 \mathrm{~g}$ of camel or cow milk powders for 5 min with $50 \mathrm{~mL}$ of petroleum ether (Schuck et al., 2012). The obtained mixture was filtered through Whatman filter paper (Whatman $\mathrm{N}^{\circ} 40$, Maidstone, UK). The resulting filtrate was evaporated at $60^{\circ} \mathrm{C}$ under vacuum to remove the petroleum ether. The SFCC (expressed in g. $100 \mathrm{~g}^{-1}$ of total fat of the analyzed powder) was measured using the following equation:

$S F F C=\frac{\text { Weight of fat after evaporation }(\mathrm{g})}{\text { Total fat of the analyzed powder }(\%)} * 10$

\subsection{X-ray photoelectron spectroscopy (XPS)}

The XPS analyses were conducted using a Kratos Axis Ultra spectrometer (Kratos Analytical, Manchester, UK) working with a monochromatic AlK $\alpha$ X-ray source $(\mathrm{E}=1486.6 \mathrm{eV} ; \mathrm{P}=90 \mathrm{~W})$ as detailed by Gaiani et al. (2011). Camel and cow milk powder samples $\left(a_{w}=0.25\right)$ were dusted on double side conductive adhesive tape which was stucked to a holder piece. The assemblage was then degassed overnight prior to analyses. The XPS was performed in an ultra-high vacuum $\left(10^{-8} \mathrm{~Pa}\right)$ and activated charge neutralizer. The analyzed powder area was of about $300 \times 600 \mu \mathrm{m}$ with a depth of $6-10 \mathrm{~nm}$. The XPS spectra were recorded with $1.0 \mathrm{eV}$ step size and $160 \mathrm{eV}$ analyzer pass energy. For the high resolution regions, the system was operating with $0.05 \mathrm{eV}$ step size (for $\mathrm{C}_{1 \mathrm{~s}}$ ) or $0.1 \mathrm{eV}$ step size (for $\mathrm{O}_{1 \mathrm{~s}}$ and $\mathrm{N}_{1 \mathrm{~s}}$ ) and $20 \mathrm{eV}$ analyzer pass energy. In both cases, the XPS system was operating in hybrid lens mode. Typical XPS survey and high resolution spectra of camel and cow milk powder samples are presented as a supplementary data in Figs. S1, S2, S3, and S4. The recorded spectra were interpreted using the Vision software from Kratos (Vision 2.2.2) based on the photoemission cross sections and the transmission coefficients given in the Vision package. The relative atomic concentration of carbon, oxygen, and nitrogen in the powder surface was quantified and integrated in the below equation system. This matrix allows the quantification of the powder surface content in relation to lactose, proteins, and fat as described by Fäldt \& Bergenståhl, 1994.

$I C=\alpha \mathbf{P} I C p+\alpha^{\prime} \mathbf{L} I C L a+\alpha^{\prime \prime} \mathbf{F} I C L i$

$I O=\alpha \mathbf{P I O p}+\alpha^{\prime} \mathbf{L} I O L a+\alpha^{\prime \prime} \mathbf{F I O L i}$

$I N=\alpha \mathbf{P I N p}+\alpha^{\prime} \mathbf{L} I N L a+\alpha^{\prime \prime} \mathbf{F I N L i}$

The $I^{\mathrm{C}}, I^{\mathrm{O}}$, and $I^{\mathrm{N}}$ are calculated from the integration of the XPS peaks areas of the $\mathrm{C}_{1 \mathrm{~s}}, \mathrm{O}_{1 \mathrm{~s}}$ and $\mathrm{N}_{1 \mathrm{~s}}$ and represents the mole fractions of carbon, oxygen, and nitrogen at the sample surface, respectively. The $I^{\mathrm{Cp}}, I^{\mathrm{CLa}}$, and $I^{\mathrm{CLi}}$ corresponded to the mole fractions of carbon in proteins, lactose, and fat; The $I^{\mathrm{OP}}, I^{\mathrm{Ola}}$, and $I^{\mathrm{OLi}}$ corresponded to the mole fractions of oxygen in proteins, lactose, and fat; The $I^{\mathrm{NP}}, I^{\mathrm{NLa}}$, and $I^{\mathrm{NLi}}$ corresponded to the mole fractions of nitrogen in proteins, lactose, and fat. These values were obtained from studying the surface composition of the pure fractions of casein, whey, anhydrous fat, and lactose monohydrate powders (Gaiani et al., 2010). Finally, the powder surface content in proteins, lactose and fats is deduced by solving the matrix and by calculating the $\boldsymbol{\alpha P}, \boldsymbol{\alpha}^{\prime} \mathbf{L}$, and $\boldsymbol{\alpha}$ 'F, respectively.

\subsection{Scanning electron microscopy (SEM)}

The surface microstructure of the different produced powders was performed at a water activity of 0.25 . The powder samples were rapidly seeded onto a double-sided adhesive tape, which was fixed on aluminum discs to avoid moisture adsorption. The samples were then covered with carbon, using a BAL-TEC SCD 005 sputter coater (Bal-Tec Co., Balzers, Liechtenstein). Micrographs were, then, observed at a magnification of $8.0 \mathrm{~K}$, using a Hitachi S-4700 (Hitachi, Tokyo, Japan) operating with an accelerating voltage of $4 \mathrm{kV}$.

The surface roughness (Sections of $5 \mu \mathrm{m} \times 5 \mu \mathrm{m}, 160$ pixels $\mu \mathrm{m}^{-1}$ ) was evaluated using at least 3 SEM micrographs per sample (magnification $8.0 \mathrm{k}, 32$ bit, $2500 \times 1875$ pixels $(\mathrm{L} \times \mathrm{H}), 500 \mathrm{dpi})$. The Image J software $(1.48 \mathrm{~V}$, National Institutes of Health, USA), including the SurfCarJ 1q plugin (Chinga, Johnsen, Dougherty, Berli, \& Walter, 2007), was used to appraise the average roughness ( $\mathrm{Ra}$ ) according to the following equation:

$R a=\frac{1}{N x N y} \sum_{i=1}^{N x} \sum_{j=1}^{N y}|(z i j-z m e a n)|$

where $z_{i j}$ represents the height of a given pixel, $\mathrm{z}_{\text {mean }}$ represents the height average of all pixels of the analyzed section; $N_{x}$ and $N_{y}$ are the 
numbers of pixels in the $x$ and $y$ directions.

\subsection{Confocal laser scattering microscopy (CLSM)}

The fats and proteins distribution within camel and cow milk powders were observed by CLSM with an inverted microscope Nikon TE2000 Eclipse C1si (Nikon, Champigny-sur-Marne, France). The Nile Red and Fast Green fluorescent probes were used to label fats and proteins, respectively. The powders were firstly dispersed in PEG-200, then stained with a probe mixture for $30 \mathrm{~min}$ at $20^{\circ} \mathrm{C}$. Observations were realized with a $40 \times$ oil immersion objective (numerical aperture, NA 1.3). He- $\mathrm{Ne}_{2}$ wavelengths of $543 \mathrm{~nm}$ and $633 \mathrm{~nm}$ were used to excite the probes labelling fats and proteins. The presented micrographs were the average of at least five pictures of the different stained powders (WDMP: Fig. 2A and PSCMP: Fig. 2B).

\subsection{Dynamic scanning calorimetry (DSC)}

The thermal properties of both encapsulated and surface free fat of camel and cow milk fats were investigated using a differential scanning calorimeter (TA Q-1000, TA Instruments, Eschborn, Germany). The calibration of the DSC system was achieved with Indium (melting point $156.6^{\circ} \mathrm{C}$ ). Ten milligrams of each powder sample were sealed in aluminum hermetic pans at $4{ }^{\circ} \mathrm{C}$, then, they were immediately placed in the DSC analyzer chamber, taking into account the storing temperature $\left(4{ }^{\circ} \mathrm{C}\right.$ ), and equilibrated at $-5^{\circ} \mathrm{C}$ for $1 \mathrm{~min}$. The crystallization profiles were recorded from $-30{ }^{\circ} \mathrm{C}$ to $65^{\circ} \mathrm{C}$ (heating rate: $1{ }^{\circ} \mathrm{C} \mathrm{min}^{-1}$ ) and were analyzed using The TA Universal Analysis 2000 software (Ta instruments, Waters LLC).

\subsection{Statistical analysis}

All analyses and measurements of this work were carried out in triplicate. Results were given as mean and standard deviation values. The statistical differences were evaluated using SPSS 19 software (IBM SPSS statistics, Version 19, USA) following the one-way ANOVA and the Tukey post-hoc test with a confidence level of $95 \%$.

\section{Results and discussion}

\subsection{Milks and powders chemical composition}

The composition of camel and cow milks is presented in Table 1. The results indicated that camel and cow milks presented similar lactose and fat contents ( $p>0.05$, Table 1$)$. Nevertheless, both skimmed and partially skimmed cow milks contained higher protein amounts as compared with camel milks' ( $\mathrm{p} \leq 0.05$, Table 1 ). It is important to note that skimmed or whole camel milks presented higher whey protein content and lower caseins amount in comparison with those of cow milks ( $\mathrm{p} \leq 0.05$, Table 1$)$. The differences found in both protein content and distribution, between camel and cow milks, were in agreement with studied by Felfoul et al. (2016). Indeed, the study also reported that unlike the whey fraction, the casein content of cow milk was significantly higher than that of camel milk. Moreover, the composition analysis indicated that camel milk contained significantly higher ash

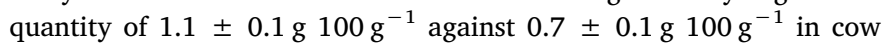
milk ( $\mathrm{p} \leq 0.05$, Table 1 ). In this current study, the ash content of camel milk was higher than the value reported by Felfoul et al. (2016) and Konuspayeva, Faye, and Loiseau (2009). The studies indicated that the

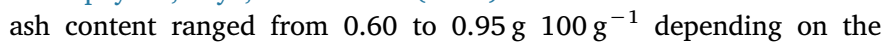
feeding nature and the water availability to the camel's herd.

The physicochemical composition of camel (WDMP and SDMP) and cow (PSCMP and SCMP) milk powders is shown in Table 1. The water activity of all produced powders were close to 0.25 ( $p>0.05$, Table 1 ) which was unaffected by the fat content of both camel and cow milk powders ( $p>0.05$, Table 1 ). Similar findings were reported by other authors which stated that fat did not interact with water during dehydration of milk and did not change the final water activity of the resulting powder (Jouppila, Kansikas, \& Roos, 1997; Schuck et al., 2005). As observed in milk composition, WDMP and PSCMP presented the same lactose content $\left(\approx 40 \mathrm{~g} 100 \mathrm{~g}^{-1}, \mathrm{p}>0.05\right.$, Table 1$)$. The latter was slightly lower than the lactose content $\left(43.57 \pm 0.91{\left.\mathrm{~g} 100 \mathrm{~g}^{-1}\right)}^{-1}\right.$ reported by Ho et al. (2019). By removing fat, the lactose content of both powders increased significantly ( $\mathrm{p} \leq 0.05$, Table 1$)$. Furthermore,

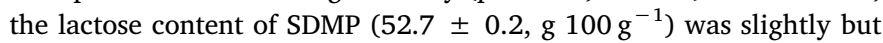
significantly lower than that of SCMP $\left(54.0 \pm 0.2 \mathrm{~g} \mathrm{100g}^{-1}, \mathrm{p} \leq 0.05\right.$, Table 1). Either skimmed or not, the total proteins and fats contents were statistically equal in camel and cow milk powders ( $\mathrm{p}>0.05$, Table 1). Similarly to milk composition, the casein's fraction of camel milk powders were significantly lower than cow's ( $\mathrm{p} \leq 0.05$, Table 1 ). In addition, higher whey protein content was measured in camel milk powder as compared to cow's ( $\mathrm{p} \leq 0.05$, Table 1 ). Likewise, camel milk powders presented higher ash content $(8.8 \pm 0.1, \mathrm{p} \leq 0.05$, Table 1$)$. In this current study, the ash content of camel milk powder was higher than the value reported by Sulieman et al. (2014). The studies acknowledged that the ash contents ranged between 6.93 and $7.69 \mathrm{~g}$ $100 \mathrm{~g}^{-1}$. This result could be related to the high ash content of camel milk before the drying process.

\subsection{Surface chemical composition}

The relative elemental composition of camel and cow milk powders is presented in Table 2. Analysis of the XPS survey of WDMP and PSCMP indicated the existence of three peaks corresponding to Carbone 'C' $\quad(84.3 \pm 4.2 \%$ and $83.2 \pm 4.1 \%, \quad \mathrm{p}>0.05), \quad$ Azote ' $\mathrm{N}$ ' $(2.6 \pm 0.1 \%$ and $3.5 \pm 0.2 \%, \quad \mathrm{p} \leq 0.05)$, and Oxygen ' $\mathrm{O}$ ' $(12.7 \pm 0.6 \%$ and $12.9 \pm 0.6 \%, p>0.05)$, respectively. Fat removal for skimmed camel and cow milk powders resulted in the appearance of the Ca 2 p peak. The XPS analysis showed that SDMP and SCMP spectra were composed of $\mathrm{C}(66.5 \pm 3.3 \%$ and $66.3 \pm 3.3 \%, \mathrm{p}>0.05), \mathrm{N}$

Table 1

Physicochemical characteristics of camel and cow milks and powders.

\begin{tabular}{|c|c|c|c|c|c|c|c|c|}
\hline & \multicolumn{4}{|l|}{ Milks } & \multicolumn{4}{|l|}{ Powders } \\
\hline & WDM & PSCM & SDM & SCM & WDMP & PSCMP & SDMP & SCMP \\
\hline$a_{w}$ & $0.962 \pm 0.01^{\mathrm{a}}$ & $0.961 \pm 0.01^{\mathrm{a}}$ & $0.963 \pm 0.01^{a}$ & $0.964 \pm 0.01^{\mathrm{a}}$ & $0.250 \pm 0.01^{\mathrm{a}}$ & $0.249 \pm 0.01^{\mathrm{a}}$ & $0.251 \pm 0.01^{a}$ & $0.249 \pm 0.01^{\mathrm{a}}$ \\
\hline Total solids & $11.6 \pm 0.2^{\mathrm{a}}$ & $11.7 \pm 0.2^{\mathrm{a}}$ & $9.0 \pm 0.3^{\mathrm{b}}$ & $9.1 \pm 0.1^{\mathrm{b}}$ & $96.9 \pm 0.4^{\mathrm{a}}$ & $96.5 \pm 0.4^{\mathrm{a}}$ & $96.8 \pm 0.5^{\mathrm{a}}$ & $96.3 \pm 0.1^{\mathrm{a}}$ \\
\hline Lactose & $4.7 \pm 0.1^{\mathrm{a}}$ & $4.9 \pm 0.1^{\mathrm{a}}$ & $5.1 \pm 0.2^{b}$ & $5.3 \pm 0.1^{b}$ & $40.7 \pm 0.1^{\mathrm{a}}$ & $40.4 \pm 0.2^{\mathrm{a}}$ & $52.7 \pm 0.2^{b}$ & $54.0 \pm 0.2^{c}$ \\
\hline Proteins & $2.8 \pm 0.1^{a}$ & $3.2 \pm 0.1^{b}$ & $2.7 \pm 0.1^{\mathrm{a}}$ & $3.1 \pm 0.1^{b}$ & $27.3 \pm 0.5^{\mathrm{a}}$ & $27.8 \pm 0.1^{\mathrm{a}}$ & $33.3 \pm 0.2^{b}$ & $33.5 \pm 0.5^{b}$ \\
\hline Caseins & $1.9 \pm 0.1^{\mathrm{a}}$ & $2.4 \pm 0.1^{b}$ & $1.8 \pm 0.1^{\mathrm{a}}$ & $2.3 \pm 0.1^{b}$ & $20.3 \pm 0.5^{\mathrm{a}}$ & $22.1 \pm 0.1^{b}$ & $25.8 \pm 0.2^{c}$ & $27.3 \pm 0.4^{\mathrm{d}}$ \\
\hline Whey & $0.9 \pm 0.1^{\mathrm{a}}$ & $0.6 \pm 0.1^{b}$ & $0.9 \pm 0.1^{\mathrm{a}}$ & $0.6 \pm 0.1^{b}$ & $7.0 \pm 0.3^{\mathrm{a}}$ & $5.8 \pm 0.1^{b}$ & $7.4 \pm 0.1^{\mathrm{a}}$ & $6.2 \pm 0.1^{c}$ \\
\hline Total fats & $2.7 \pm 0.1^{\mathrm{a}}$ & $2.7 \pm 0.1^{a}$ & $0.1 \pm 0.01^{b}$ & $0.1 \pm 0.01^{b}$ & $20.5 \pm 0.2^{\mathrm{a}}$ & $21.0 \pm 0.5^{\mathrm{a}}$ & $1.0 \pm 0.1^{b}$ & $1.0 \pm 0.1^{b}$ \\
\hline Ash & $1.2 \pm 0.1^{\mathrm{a}}$ & $0.7 \pm 0.1^{b}$ & $1.1 \pm 0.1^{\mathrm{a}}$ & $0.6 \pm 0.1^{b}$ & $8.4 \pm 0.1^{\mathrm{a}}$ & $7.1 \pm 0.1^{\mathrm{b}}$ & $8.8 \pm 0.1^{c}$ & $7.8 \pm 0.1^{\mathrm{d}}$ \\
\hline
\end{tabular}

WDM: whole camel milk; PSCM: partially skim cow milk; SDM: skim camel milk; SCM: skim cow milk; P: powder; The composition is expressed in $g$ 100g ${ }^{-1}$; Same letter in the same row for milks or powders represent the statistical data significance $(p>0.05)$. 
Table 2

Complete elemental composition of camel and cow milk powders.

\begin{tabular}{|c|c|c|c|c|}
\hline Elements & WDMP & PSCMP & SDMP & SCMP \\
\hline $\mathrm{O}_{1 \mathrm{~s}}(\%)$ & $12.7 \pm 0.6^{\mathrm{a}}$ & $12.9 \pm 0.6^{\mathrm{a}}$ & $23.1 \pm 1.1^{\mathrm{b}}$ & $21.0 \pm 1.1^{\mathrm{b}}$ \\
\hline $\mathrm{N}_{1 \mathrm{~s}}(\%)$ & $2.6 \pm 0.1^{\mathrm{a}}$ & $3.5 \pm 0.2^{b}$ & $8.8 \pm 0.4^{c}$ & $11.2 \pm 0.6^{\mathrm{d}}$ \\
\hline $\mathrm{C}_{1 \mathrm{~s}}(\%)$ & $84.3 \pm 4.2^{\mathrm{a}}$ & $83.2 \pm 4.1^{\mathrm{a}}$ & $66.5 \pm 3.3^{b}$ & $66.3 \pm 3.3^{b}$ \\
\hline $\mathrm{C}-(\mathrm{C}, \mathrm{H})$ & $76.3 \pm 3.8^{\mathrm{a}}$ & $72.8 \pm 3.6^{\mathrm{a}}$ & $44.7 \pm 2.2^{b}$ & $46.9 \pm 2.3^{b}$ \\
\hline $\mathrm{C}-\mathrm{O}$ & $15.8 \pm 0.8^{\mathrm{a}}$ & $17.3 \pm 0.8^{\mathrm{a}}$ & $36.7 \pm 1.8^{b}$ & $33.9 \pm 1.7^{b}$ \\
\hline $\mathrm{C}=\mathrm{O}$ & $3.2 \pm 0.2^{\mathrm{a}}$ & $4.3 \pm 0.2^{b}$ & $15.2 \pm 0.8^{\mathrm{c}}$ & $14.6 \pm 0.7^{\mathrm{c}}$ \\
\hline $\mathrm{O}-\mathrm{C}=\mathrm{O}$ & $4.6 \pm 0.2^{\mathrm{a}}$ & $5.7 \pm 0.3^{b}$ & $3.3 \pm 0.2^{c}$ & $4.5 \pm 0.2^{\mathrm{a}}$ \\
\hline $\mathrm{Ca}_{2 \mathrm{p}}(\%)$ & n.id & n.id & $0.20 \pm 0.01^{\mathrm{a}}$ & $0.40 \pm 0.02^{b}$ \\
\hline Stoichiometry: $\mathrm{C} \backslash \mathrm{O}$ & $6.6 \pm 0.3^{\mathrm{a}}$ & $6.5 \pm 0.3^{a}$ & $2.9 \pm 0.1^{b}$ & $3.1 \pm 0.1^{b}$ \\
\hline
\end{tabular}

WDMP: whole camel milk powder; PSCMP: partially skim cow milk powder; SDMP: skim camel milk powder; SCMP: skim cow milk powder; n.id: not identified; Same letter in the same row represent the statistical data significance $(\mathrm{p}>0.05)$.

Table 3

Surface characterization of the spray-dried camel and cow milks powders at a water activity of 0.25 .

\begin{tabular}{lllll}
\hline & WDMP & PSCMP & SDMP & \multicolumn{1}{l}{ SCMP } \\
\hline \multicolumn{2}{l}{ Surface composition (\%) } & & & \\
Proteins & $17.5 \pm 0.9^{\mathrm{a}}$ & $23.1 \pm 1.1^{\mathrm{b}}$ & $59.0 \pm 2.9^{\mathrm{c}}$ & $75.0 \pm 3.7^{\mathrm{d}}$ \\
Fats & $81.6 \pm 4.1^{\mathrm{a}}$ & $77.0 \pm 3.8^{\mathrm{a}}$ & $22.3 \pm 1.1^{\mathrm{b}}$ & $15.6 \pm 0.7^{\mathrm{c}}$ \\
Lactose & $0.8 \pm 0.1^{\mathrm{a}}$ & $0.0 \pm 0.0^{\mathrm{b}}$ & $17.7 \pm 0.8^{\mathrm{c}}$ & $8.7 \pm 0.4^{\mathrm{d}}$ \\
Ash & $0.0 \pm 0.0^{\mathrm{a}}$ & $0.0 \pm 0.0^{\mathrm{a}}$ & $1.1 \pm 0.1^{\mathrm{b}}$ & $1.0 \pm 0.5^{\mathrm{b}}$ \\
Surface Free Fat & $23.5 \pm 2.1^{\mathrm{a}}$ & $30.2 \pm 1.0^{\mathrm{b}}$ & $14.4 \pm 0.1^{\mathrm{c}}$ & $10.0 \pm 1.0^{\mathrm{d}}$ \\
$\quad$ content * & & & & \\
$\begin{array}{l}\text { Surface Roughness } \\
\quad(\mathrm{nm})\end{array}$ & $7.6 \pm 0.4^{\mathrm{a}}$ & $10.1 \pm 0.3^{\mathrm{b}}$ & $5.6 \pm 0.7^{\mathrm{c}}$ & $11.3 \pm 0.7^{\mathrm{d}}$ \\
$\quad$ & & & &
\end{tabular}

WDMP: whole camel milk powder; PSCMP: partially skim cow milk powder; SDMP: skim camel milk powder; SCMP: skim cow milk powder; *: surface free fat content expressed as $\mathrm{g} 100 \mathrm{~g}^{-1}$ of total fat. Same letter in the same row represent the statistical data significance $(\mathrm{p}>0.05)$.

A

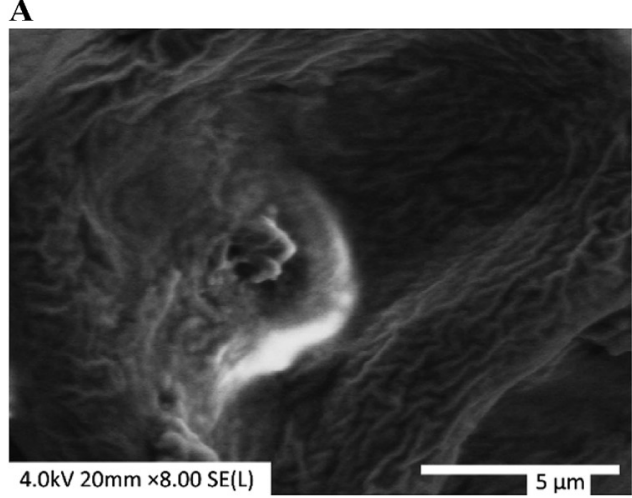

C

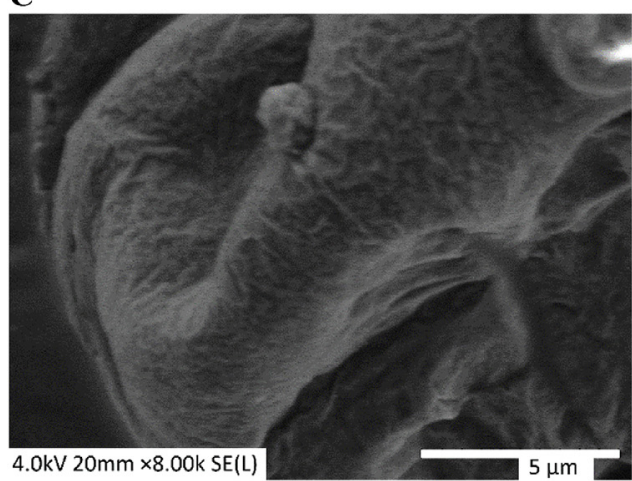

$(8.8 \pm 0.4 \%$ and $11.2 \pm 0.6 \%, \mathrm{p} \leq 0.05), \mathrm{O}(23.1 \pm 1.1 \%$ and $21.0 \pm 1.1, \mathrm{p}>0.05)$ and $\mathrm{Ca}(0.20 \pm 0.01 \%$ and $0.40 \pm 0.02 \%$, $\mathrm{p} \leq 0.05$ ), respectively. Regardless of the fat content, there was no statistical difference in Carbone and Oxygen elementary composition of cow and camel milk powders ( $p>0.05)$. Nevertheless, significant higher azote $(\mathrm{p} \leq 0.05)$ and calcium contents were observed for cow milk powders. The deconvolution of $\mathrm{C}_{1 \mathrm{~s}}$ spectra indicated the presence of 4 distinct sub-peaks ( $\mathrm{C}-\mathrm{C}, \mathrm{C}-\mathrm{COOH}, \mathrm{C}-\mathrm{O}, \mathrm{C}=\mathrm{O}$ and $\mathrm{O}-\mathrm{C}=\mathrm{O}$ ) in all samples. These sub-peaks corresponded to the different functions of the macromolecules (proteins, fats and lactose) composing the powder surface.

The surface composition of camel and cow milk powders is summarized in Table 3. The surface fat coverage of WDMP (81.6 $\pm 4.1 \%$, Table 3) was insignificantly higher than that of PSCMP $(77.7 \pm 3.8 \%$, $\mathrm{p}>0.05$, Table 3). The WDMP presented $0.8 \pm 0.04 \%$ of lactose at the surface; whereas, the PSCMP surface was lactose free ( $\mathrm{p} \leq 0.05$, Table 3). A general predominance of fat at the particles' surface composition of WDMP and PSCMP (Table $3, \mathrm{p} \leq 0.05$ ) was observed. However, by removing fats from milks, the surface of SDMP and SCMP

\section{B}

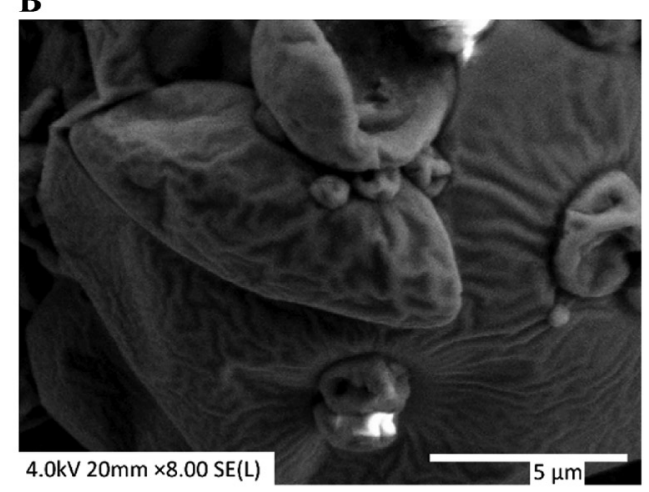

D

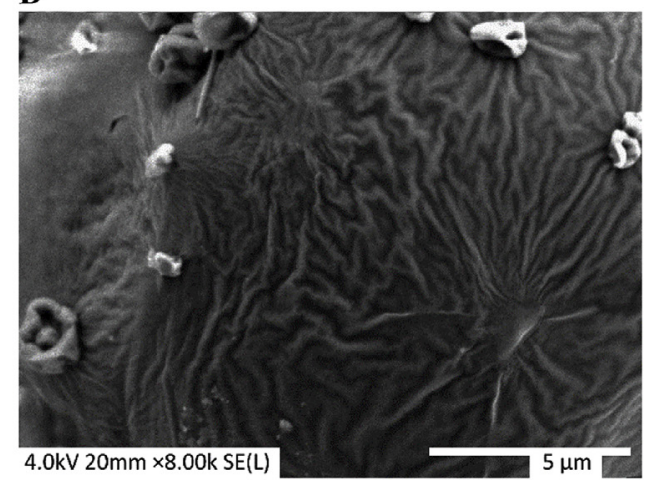

Fig. 1. Surface microstructure of WDMP (A), PSCMP (B), SDMP (C) and SCMP (D) particle surface as observed by SEM at a water activity of 0.25 (magnification of $8.0 \mathrm{~K}$, scale $5 \mu \mathrm{m})$. 


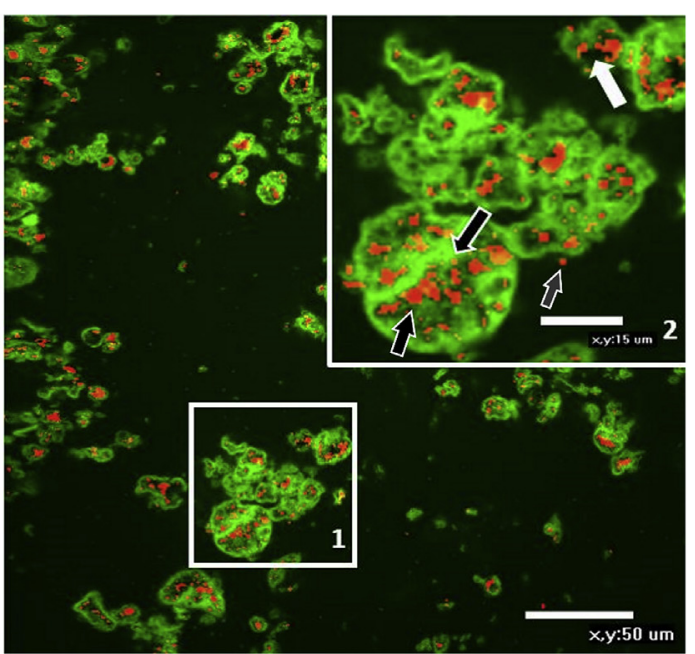

B

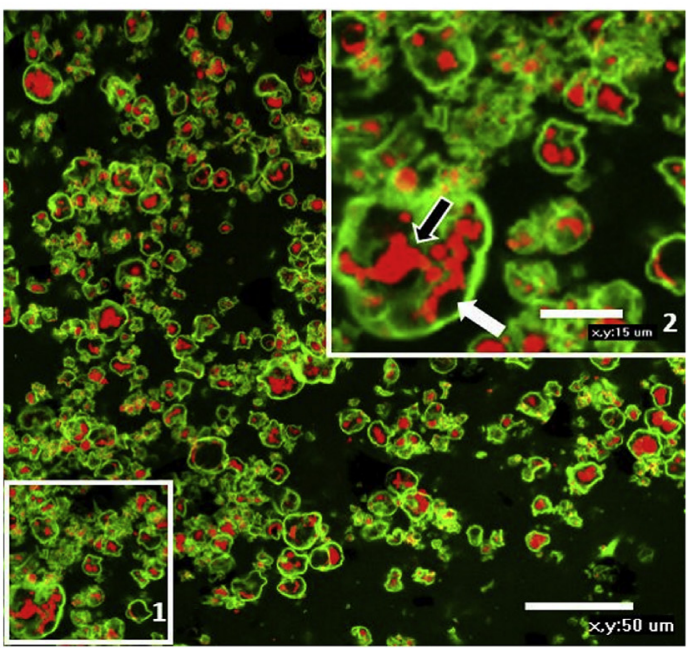

Fig. 2. CLSM micrographs of camel (A) and cow (B) milk powder. The protein and fat network were stained with Fast Green and Nile blue chloride, respectively. The black and white arrows indicate the encapsulated fats and the vacuoles, respectively. (For interpretation of the references to color in this figure legend, the reader is referred to the Web version of this article.)

became enriched with proteins and lactose, proteins being the main relevant compounds at their surfaces $(59 \pm 2.9 \%$ and $75 \pm 3.7 \%$ for SDMP and SCMP, respectively, Table $3, \mathrm{p} \leq 0.05)$. Interestingly, the lactose content of SDMP $(17.7 \pm 0.8 \%)$ was significantly twice the amount observed in SCMP $(8.7 \pm 0.4 \%, \mathrm{p} \leq 0.05$, Table 3$)$. Trace minerals were only measured at the surface of both SDMP and SCMP. In this regard, it is important to notice that even at low total fat content $\left(\approx 1 \mathrm{~g} \mathrm{~L}^{-1}\right.$, Table 1 ), both skimmed milk powder showed relatively high fat content at their surface $(22.3 \pm 1.1 \%$ and $15.6 \pm 0.7 \%$ for SDMP and SCMP, respectively). It is admitted that, even at low fat content (e.g. skimmed milk), the residual fat preferentially adsorbed at the air/ droplet interface and migrate to the surface at relatively high concentration (Gaiani et al., 2009; Nijdam \& Langrish, 2006). Importantly, the surface fat at SDMP $(22.3 \pm 1.1 \%)$ was significantly higher for SCMP (15.6 $\pm 0.7 \%, p \leq 0.05$, Table 3$)$. In the present study, the surface composition of cow milk powders was in agreement with several other works (Fyfe, Kravchuk, Nguyen, Deeth, \& Bhandari, 2011; Gaiani et al., 2007; Kim et al., 2002; Kim, Chen, \& Pearce, 2009; Murrieta-Pazos et al., 2012; 2011). According to these previous studies, the surface composition of whole cow milk powder varied from $71 \%$ to $98 \%$ of fat, $7.2 \%$ to $31 \%$ of protein, and $0.8 \%$ to $13 \%$ of lactose. For skim cow milk powder, the surface composition ranged from $16.5 \%$ to $46.6 \%$ of fat, $34.0 \%$ to $47 \%$ of protein, and $16.8 \%$ to $46 \%$ of lactose.

Besides, the calculated values for $\mathrm{C} / \mathrm{O}$ were equal to $6.6 \pm 0.3$, $6.5 \pm 0.3,2.9 \pm 0.3$, and $3.1 \pm 0.1$ for WDMP, PSCMP, SDMP and SCMP, respectively (Table 2 ). The $\mathrm{C} / \mathrm{O}$ ratio reflected the surface hydrophobicity of the studied powders. The results revealed camel and cow milk powders presented a similar surface hydrophobicity (p > 0.05, Table 2).

\subsection{Surface microstructure and roughness}

The surface aspect of camel and cow milk powders was analyzed using SEM micrographs. Visually, the surface of WDMP (Fig. 1A), SDMP (Fig. 1B), PSCMP (Fig. 1C), and SCMP (Fig. 1D) appeared homogeneous with the presence of distinguishable wrinkles (i.e. brain-type surface). Several previous studies have reported a similar surface's aspect for cow milk powders (Fyfe et al., 2011; Kim et al., 2002; Murrieta-Pazos et al., 2011). The surface roughness $(\mathrm{Ra})$ of PSCMP $(10.1 \pm 0.3 \mathrm{~nm})$ was significantly lower compared to SCMP's $(11.3 \pm 0.7 \mathrm{~nm}, \mathrm{p} \leq 0.05$, Table 3). The analysis of cow milk powders Ra agreed with those of Murrieta-Pazos et al. (2011). The studies reported a lower surface roughness in whole cow milk powder against the skimmed one. The decrease of Ra was attributed to the presence of free fat at the cow milk powder surface (Fyfe et al., 2011; Gaiani et al., 2006; Kelly et al., 2016). The surface roughness of WDMP $(\mathrm{Ra}=7.6 \pm 0.4 \mathrm{~nm}$, Table 3$)$ decreased significantly to $5.6 \pm 0.7 \mathrm{~nm}$ for SDMP ( $\mathrm{p} \leq 0.05$, Table 3 ), making camel milk powder's surface smoother. Furthermore, the surface roughness of both whole and skimmed camel milk powders was significantly lower than cow's. The assumption is that a high amount of camel milk fats quickly adsorbed at the air/water interface as surface free fat, even at low milk-fat concentration.

The analysis of the surface free fat content (SFFC) of camel and cow milk powders revealed that the SFFC decreased significantly from $23.5 \pm 2.1 \%$ for WDMP and $30.2 \pm 1.0 \%$ in PSCMP to $14.4 \pm 0.1 \%$ for SDMP and $10.0 \pm 1.0 \%$ for SCMP ( $\leq 0.05$, Table 3 ). This result indicated that the cow milk fats were poorly encapsulated as compared to camel milk fat at higher milk fat content. Results related to cow milk fat are in agreement with similar other observations which highlighted their poor encapsulation (Gaiani et al., 2009; A.; Millqvist-Fureby, Elofsson, \& Bergenståhl, 2001). Nevertheless, camel milk powder presented lower SFFC than cow's ( $\mathrm{p} \leq 0.05$, Table 3 ), indicating higher encapsulation extent of camel milk fat. The high fat surface coverage (XPS results, Table 3) together with the low free fat content of camel milk powders advanced that most of camel milk fat are encapsulated underneath the protein in the first $6-10 \mathrm{~nm}$ (the studied thickness) of the powder surface. This will promote the exposure of amorphous lactose to the surface, leading to the decrease of the surface roughness of camel milk powders.

\subsection{Surface and encapsulated fat's distribution}

The distribution of camel (DMFG) and cow milk fat globules (CMFG) within the powders were characterized based on CLSM observations (Fig. 2). Since SDMP and SCMP showed a relatively low fat

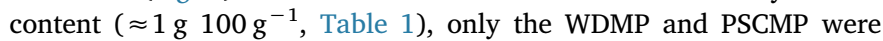
studied (Fig. 2A and B, respectively). The obtained CLSM micrographs clearly highlighted that both size and distribution of DMFG and CMFG were relatively different within WDMP and PSCMP (Fig. 2). Indeed, the CLSM observations showed that the DMFG were organized in small and less coalesced patches (black arrow, Fig. 2A). The CMFG, instead, were organized in large coalesced patches, indicating that cow milk fat globules were disrupted during drying (black arrow, Fig. 2B). The coalesced CMFG were mostly located near and within the particle's vacuoles (white arrow, Fig. 2B). This CMFG disposition promoted their extraction by the solvent, which explained the high SFFC value of cow milk powder (Table 3). Interestingly, it is worth noted that the DMFG 

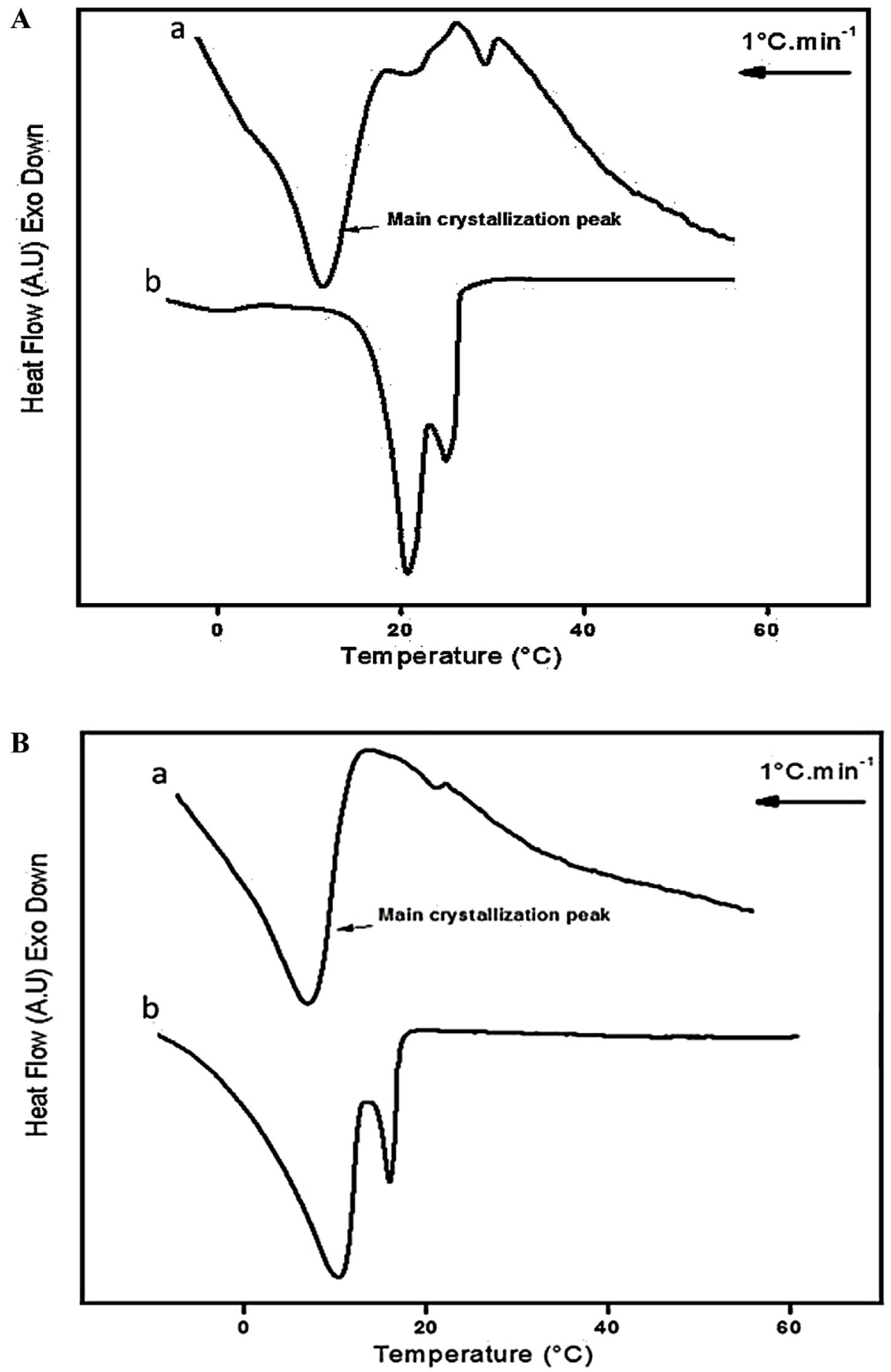

Fig. 3. Crystallization profiles camel (A) and cow (B) milk fat globules. a: encapsulated fat. b: anhydrous surface free fat.

preserved their initial structure and appeared more spread within the powder particle. Most of these globules were encapsulated just under the protein-lactose matrix (green color) near the surface (black arrow, Fig. 2A), while a small portion of DMFG was observed outside the WDMP particles (gray arrow, Fig. 2A).

Several studies have reported that camel milk fat globules had smaller mean size diameter and higher mechanical resistance to disruption as compared to cow milk fat globules (Attia, Kherouatou, Fakhfakh, Khorchani, \& Trigui, 2000; Karray, Lopez, Lesieur, \& Ollivon, 2005; Mehaia, 1995). These differences could explain the behavior of camel milk fat globules (DMFG) during drying of whole camel milk. Indeed, the mean diameter of DMFG $(2.7 \pm 0.1 \mu \mathrm{m})$, as measured by laser diffraction, was significantly lower than CMFG one $(4.2 \pm 0.3 \mu \mathrm{m}, \mathrm{p} \leq 0.05)$. The lower size distribution of DMFG as compared to CMFG allowed assimilating their behavior during spraydrying to that of homogenized and non-homogenized cow milk fat globules. Indeed, during whole milk homogenization, the fat globules size distribution is reduced and their surface is covered with casein micelles through $\kappa$-casein interactions (Ye, Anema, \& Singh, 2007). The presence of proteins (i.e. surface active compounds) at the fat globules surface together with their low size distribution enhanced their rapid exposure to the surface of dried particles (Fyfe et al., 2011; Vignolles et al., 2009; Ye et al., 2007). Moreover, it was demonstrated that even in homogenized emulsion, a small proportion of fat globules is likely 
subjected to limited coalescence (Anna Millqvist-Fureby, 2003; Vignolles et al., 2009). Results of this current work confirmed that the small size (rapid transport toward the surface) together with the high mechanical resistance to disruption (limited coalescence) enhanced the dispersion of DMFG within the camel milk powder particles.

\subsection{Crystallization temperature of encapsulated and surface free fat}

The recorded crystallization exotherms for EDMF (Encapsulated Camel Milk Fat) underlined the existence of three crystallization peaks (Fig. 3Aa) at $30.7 \pm 0.2{ }^{\circ} \mathrm{C}, 26.2 \pm 0.2^{\circ} \mathrm{C}$, and $18.3 \pm 0.5{ }^{\circ} \mathrm{C}$ (main crystallization peak). However, The ECMF (Encapsulated Cow Milk Fat) went through two crystallization peaks with significantly $(\mathrm{p} \leq 0.05)$ lower temperatures $\left[24.8 \pm 0.1{ }^{\circ} \mathrm{C}\right.$ and $15.6 \pm 0.2^{\circ} \mathrm{C}$ (main crystallization peak), Fig. 3Ba]. For a better understanding, the crystallization temperatures of the anhydrous surface free fats of camel (ADMF) and cow (ACMF) milks were analyzed. The crystallization profiles showed the presence of 3 exothermic peaks with significantly higher onset temperatures for $\mathrm{ADMF} \quad\left(27.1 \pm 0.2^{\circ} \mathrm{C}, 22.8 \pm 0.4{ }^{\circ} \mathrm{C}\right.$, and $4.7 \pm 0.2^{\circ} \mathrm{C}$, Fig. $3 \mathrm{Ab}$ ). However, the ACMF showed 2 exothermic peaks with crystallization temperatures $\left(19.4 \pm 0.9^{\circ} \mathrm{C}\right.$ and $13.2 \pm 0.3^{\circ} \mathrm{C}$, Fig. $\left.3 \mathrm{Bb}\right)$. The thermograms underlined that the crystallization temperature significantly $(\mathrm{p} \leq 0.05)$ decreased significantly from $27.1 \pm 0.2{ }^{\circ} \mathrm{C}$ for ADMF (Fig. $3 \mathrm{Ab}$ ) and $19.4 \pm 0.9^{\circ} \mathrm{C}$ for ACMF (Fig. 3Bb) to $18.3 \pm 0.5^{\circ} \mathrm{C}$ EDMF (Fig. 3Aa) and $15.2 \pm 0.2{ }^{\circ} \mathrm{C}$ for ECMF (Fig. 3Ba).

The findings in this current study clearly indicated that the crystallization temperature of the anhydrous surface free fat for both camel and cow milks, were significantly $(\mathrm{p} \leq 0.05)$ higher than for the encapsulated fats within the powder matrix. Moreover, camel milk fats, either encapsulated or anhydrous had crystallized at significantly higher temperature than those of cow milk $(p \leq 0.05)$. These results indicated that camel milk fats would solidify faster than cow's, which could hinder their mobility. At high milk fat content, the highest crystallization temperature together with lowest size distribution (see section 3.4) endorsed the encapsulation of a great amount of camel milk fat inside the particle powder. However, at low fat content, the residual camel milk fat adsorbs rapidly to air/water interface (Gaiani et al., 2009; Nijdam \& Langrish, 2006) and quickly solidify at the powder surface. This explains the higher free fat surface content of SDMP as compared to SCMP (Table 3). This fact further confirms the lower roughness and the smoother aspect of SDMP surface (Table 3).

\section{Conclusion}

In this study, the surface elemental composition of camel and cow milk powders was investigated. The XPS analysis highlighted that camel milk powder exhibited higher lactose and fat contents at the first $5-10 \mathrm{~nm}$ of the surface layer. The analysis of camel milk powders' surface (SEM observations) indicated significantly lower surface roughness than cow milk powder. This result was related to the high amorphous lactose content at the surface of camel milk powders (XPS data). At high milk fat concentration $\left(20 \mathrm{~g} \mathrm{~L}^{-1}\right)$, camel milk fat globules were rapidly exposed to the surface (CLSM observations) due to their low mean diameter. However, these globules quickly solidified due to their high crystallization temperature (DSC data), which endorsed their encapsulation underneath milk proteins.

\section{Declaration of competing interest}

The authors declare that they have no known competing financial interests or personal relationships that could have appeared to influence the work reported in this paper.

\section{Acknowledgement}

The authors would like to thank Mr. Ahmed ADDAD and Mr. Oussama KHELISSA (UMET: Unité Matériaux et Transformations - UMR CNRS 820, France) for assisting the SEM observation. The authors also would like to thank Ms. Sawssen Derbel-Krichen for editing and improving the form of the manuscript.

\section{Appendix A. Supplementary data}

Supplementary data to this article can be found online at https:// doi.org/10.1016/j.lwt.2019.108693.

\section{References}

Abu-Lehia, I. H. (1998). Recombined camel's milk powder. Colloques-CIRAD. In P. Bonnet (Ed.). Actes du colloque, Dromadaires et chameaux, animaux laitiers/ Dromedaries and camels, milking animals (pp. 181-184). Nouakchott, Mauritania: CIRAD Publ (1998).

Abu-Lehia, Ibrahim, H., Al-Mohizea, I. S., \& El-Behry, M. (1989). Studies on the production of ice cream from camel milk productd. Australian Journal of Dairy Technology.

Attia, H., Kherouatou, N., Fakhfakh, N., Khorchani, T., \& Trigui, N. (2000). Dromedary milk fat: Biochemical, microscopic and rheological characteristics. Journal of Food Lipids, 7(2), 95-112.

Chinga, G., Johnsen, P. O., Dougherty, R., Berli, E. L., \& Walter, J. (2007). Quantification of the 3D microstructure of SC surfaces. Journal of Microscopy, 227(3), 254-265.

Fäldt, P., \& Bergenståhl, B. (1994). The surface composition of spray-dried protein-lactose powders. Colloids and Surfaces A: Physicochemical and Engineering Aspects, 90(2-3), 183-190.

Felfoul, I., Beaucher, E., Cauty, C., Attia, H., Gaucheron, F., \& Ayadi, M. A. (2016), Deposit generation during camel and cow milk heating: Microstructure and chemical composition. Food and Bioprocess Technology, 9(8), 1268-1275.

Felfoul, I., Jardin, J., Gaucheron, F., Attia, H., \& Ayadi, M. A. (2017). Proteomic profiling of camel and cow milk proteins under heat treatment. Food Chemistry, 216, 161-169.

Fyfe, K., Kravchuk, O., Nguyen, A. V., Deeth, H., \& Bhandari, B. (2011). Influence of dryer type on surface characteristics of milk powders. Drying Technology, 29(7), 758-769.

Gaiani, C., Ehrhardt, J. J., Scher, J., Hardy, J., Desobry, S., \& Banon, S. (2006). Surface composition of dairy powders observed by X-ray photoelectron spectroscopy and effects on their rehydration properties. Colloids and Surfaces B: Biointerfaces, 49(1), $71-78$.

Gaiani, C., Morand, M., Sanchez, C., Tehrany, E. A., Jacquot, M., Schuck, P., et al. (2010). How surface composition of high milk proteins powders is influenced by spray-drying temperature. Colloids and Surfaces B: Biointerfaces, 75, 377-384.

Gaiani, C., Mullet, M., Arab-Tehrany, E., Jacquot, M., Perroud, C., Renard, a., et al. (2011). Milk proteins differentiation and competitive adsorption during spray-drying. Food Hydrocolloids, 25(5), 983-990.

Gaiani, Scher, J., Ehrhardt, J. J., Linder, M., Schuck, P., Desobry, S., et al. (2007). Relationships between dairy powder surface composition and wetting properties during storage: Importance of residual lipids. Journal of Agricultural and Food Chemistry, 55(16), 6561-6567.

Gaiani, C., Schuck, P., Scher, J., Ehrhardt, J. J., Arab-Tehrany, E., Jacquot, M., et al. (2009). Native phosphocaseinate powder during storage: Lipids released onto the surface. Journal of Food Engineering, 94(2), 130-134.

Ho, T. M., Chan, S., Yago, A. J. E., Shravya, R., Bhandari, B. R., \& Bansal, N. (2019). Changes in physicochemical properties of spray-dried camel milk powder over accelerated storage. Food Chemistry, 295, 224-233.

Jouppila, K., Kansikas, J., \& Roos, Y. H. (1997). Glass transition, water plasticization, and lactose crystallization in skim milk powder. Journal of Dairy Science, 80(12), 3152-3160.

Karray, N., Lopez, C., Lesieur, P., \& Ollivon, M. (2005). Dromedary milk fat: Thermal and structural properties 2. Influence of cooling rate. Le Lait, 85(6), 433-451.

Kelly, G. M., O'Mahony, J. A., Kelly, A. L., Huppertz, T., Kennedy, D., \& O'Callaghan, D. J. (2016). Influence of protein concentration on surface composition and physico-chemical properties of spray-dried milk protein concentrate powders. International Dairy Journal, 51, 34-40.

Kim, E. H.-J., Chen, X. D., \& Pearce, D. (2002). Surface characterization of four industrial spray-dried dairy powders in relation to chemical composition, structure and wetting property. Colloids and Surfaces B: Biointerfaces, 26(3), 197-212.

Kim, E. H.-J., Chen, X. D., \& Pearce, D. (2009). Surface composition of industrial spraydried milk powders. 2. Effects of spray drying conditions on the surface composition. Journal of Food Engineering, 94(2), 169-181.

Kim, E. H.-J., Dong Chen, X., \& Pearce, D. (2003). On the mechanisms of surface formation and the surface compositions of industrial milk powders. Drying Technology, 21(2), 265-278.

Konuspayeva, G., Faye, B., \& Loiseau, G. (2009). The composition of camel milk: A metaanalysis of the literature data. Journal of Food Composition and Analysis, 22, 95-101.

Mehaia, M. A. (1995). The fat globule size distribution in camel, goat, Ewe, and cow milk. Milchwissenschaft Milk Science International, 50, 260-263.

Merin, U., Bernstein, S., Bloch-Damti, A., Yagil, R., Van Creveld, C., Lindner, P., et al. (2001). A comparative study of milk serum proteins in camel (Camelus dromedarius) 
and bovine colostrum. Livestock Production Science, 67(3), 297-301.

Millqvist-Fureby, A. (2003). Characterisation of spray-dried emulsions with mixed fat phases. Colloids and Surfaces B: Biointerfaces, 31, 65-79.

Millqvist-Fureby, A., Elofsson, U., \& Bergenståhl, B. (2001). Surface composition of spraydried milk protein-stabilised emulsions in relation to pre-heat treatment of proteins. Colloids and Surfaces B: Biointerfaces, 21(1-3), 47-58.

Murrieta-Pazos, I., Gaiani, C., Galet, L., Calvet, R., Cuq, B., \& Scher, J. (2012a). Food powders: Surface and form characterization revisited. Journal of Food Engineering, 112(1-2), 1-21.

Murrieta-Pazos, I., Gaiani, C., Galet, L., Cuq, B., Desobry, S., \& Scher, J. (2011). Comparative study of particle structure evolution during water sorption: Skim and whole milk powders. Colloids and Surfaces B: Biointerfaces, 87(1), 1-10.

Murrieta-pazos, I., Gaiani, C., Galet, L., \& Scher, J. (2012b). Food Hydrocolloids Composition gradient from surface to core in dairy powders: Agglomeration effect. Food Hydrocolloids, 26(1), 149-158.

Nawaz, M. A., Gaiani, C., Fukai, S., \& Bhandari, B. (2016). X-ray photoelectron spectroscopic analysis of rice kernels and flours: Measurement of surface chemical composition. Food Chemistry, 212, 349-357.

Nijdam, J. J., \& Langrish, T. A. G. (2006). The effect of surface composition on the functional properties of milk powders. Journal of Food Engineering, 77(4), 919-925.

Nikolova, Y., Petit, J., Sanders, C., Gianfrancesco, A., Scher, J., \& Gaiani, C. (2015). Toward a better determination of dairy powders surface composition through XPS matrices development. Colloids and Surfaces B: Biointerfaces, 125, 12-20.

Roos, Y. H. (2002). Importance of glass transition and water activity to spray drying and stability of dairy powders. Le Lait, 82(4), 475-484.

Schuck, P., Blanchard, E., Dolivet, A., Méjean, S., Onillon, E., \& Jeantet, R. (2005). Water activity and glass transition in dairy ingredients. Le Lait, 85(4-5), 295-304.

Schuck, Dolivet, A., Méjean, S., \& Jeantet, R. (2008). Relative humidity of outlet air: The key parameter to optimize $\backslash$ moisture content and water activity of dairy powders. Dairy Science \& Technology, 88(1), 45-52.

Schuck, Jeantet, R., \& Dolivet, A. (2012). Analytical methods for food and dairy powders. John Wiley \& Sons.

Shrestha, A. K., Howes, T., Adhikari, B. P., Wood, B. J., \& Bhandari, B. R. (2007). Effect of protein concentration on the surface composition, water sorption and glass transition temperature of spray-dried skim milk powders. Food Chemistry, 104(4), 1436-1444.

Sulieman, A. M. E., Elamin, O. M., Elkhalifa, E. A., \& Laleye, L. (2014). Comparison of physicochemical properties of spray-dried camel's milk and cow's milk powder. International Journal of Food Science and Nutrition Engineering, 4(1), 15-19.

Vignolles, M. L., Lopez, C., Madec, M. N., Ehrhardt, J. J., Méjean, S., Schuck, P., et al. (2009). Fat properties during homogenization, spray-drying, and storage affect the physical properties of dairy powders. Journal of Dairy Science, 92(1), 58-70.

Walstra, P., Walstra, P., Wouters, J. T. M., \& Geurts, T. J. (2005). Dairy science and technology. CRC press.

Ye, A., Anema, S. G., \& Singh, H. (2007). Behaviour of homogenized fat globules during the spray drying of whole milk. International Dairy Journal, 17(4), 374-382.

Zouari, A., Marchesseau, S., Chevalier-Lucia, D., Raffard, G., Ayadi, M. A., \& PicartPalmade, L. (2018). Acid gelation of raw and reconstituted spray-dried dromedary milk: A dynamic approach of gel structuring. International Dairy Journal, 81, 95-103. 